\title{
Kajian Risiko Pajanan Sinar Gama dan Radon pada Pekerja di Area Terowongan Eksplorasi Uranium Remaja, Kalimantan Barat
}

\section{Risk Analysis of Gamma and Radon Exposure to Workers in Remaja Uranium Exploration Tunnel Area, West Kalimantan}

\author{
Tajudin Noor ${ }^{1,2 *}$, Mila Tejamaya ${ }^{2 *}$, Miki Arian Saputra ${ }^{1}$, Tri Purwanti ${ }^{1}$ \\ ${ }^{1}$ Pusat Teknologi Bahan Galian Nuklir-BATAN, \\ Jl. Lebak Bulus Raya No. 9, Pasar Jumat, Jakarta, Indonesia, 12440 \\ ${ }^{2}$ Departemen Keselamatan dan Kesehatan Kerja, Fakultas Kesehatan Masyarakat, \\ Universitas Indonesia, Kampus UI Depok, Indonesia, 16424 \\ *E-mail: tajudinnoor@batan.go.id, tejamaya@ui.ac.id
}

Naskah diterima: 11 Mei 2020, direvisi: 20 Mei 2020, disetujui: 23 Juni 2020

DOI: $10.17146 /$ eksplorium.2020.41.2.5882

\begin{abstract}
ABSTRAK
Kajian risiko pajanan radiasi gama dan gas radon dilakukan di area terowongan eksplorasi uranium dalam upaya melindungi pekerja dari bahaya radiasi pengion di tempat kerja. Pengukuran pajanan sinar gama dan konsentrasi gas radon dilakukan di dalam terowongan eksplorasi uranium Remaja dan sekitar kamp pekerja di daerah Kalan, Kalimantan Barat. Pajanan sinar gama diukur menggunakan surveimeter gama, sementara pajanan radon $(222 \mathrm{Rn} / 220 \mathrm{Rn})$ menggunakan detektor pasif RADUET. Konsentrasi gas radon dan toron di dalam terowongan secara umum cukup tinggi, berkisar antara 188,84 hingga 495,86 Bq/ $\mathrm{m}^{3}$ (rata-rata $375,80 \mathrm{~Bq} / \mathrm{m}^{3}$ ) sementara toron berkisar antara 58,07 hingga $340,73 \mathrm{~Bq} / \mathrm{m}^{3}$ (rata-rata $189,80 \mathrm{~Bq} / \mathrm{m}^{3}$ ). Nilai tersebut berada di atas reference level radon $\left(300 \mathrm{~Bq} / \mathrm{m}^{3}\right)$ yang disaranakan oleh International Commission on Radiation Protection (ICRP). Dosis efektif tahunan sinar gama mencapai nilai $147,88 \mathrm{mSv}$ di dalam terowongan eksplorasi. Nilai tersebut berada di atas nilai batas dosis untuk pekerja, yaitu $20 \mathrm{mSv}$. Pengendalian pajanan sangat penting dilakukan dengan memenuhi prinsip "as low as reasonably achievable" (ALARA) dan proteksi radiasi eksterna untuk melindungi pekerja di dalam terowongan dari masalah kesehatan yang disebabkan oleh pajanan dari sinar gama, radon, dan toron.
\end{abstract}

Kata kunci: penilaian risiko, radiasi gamma, radon, pekerja terowongan, terowongan uranium

\begin{abstract}
A risk assessment of gamma radiation and radon gas exposure is carried out in the uranium exploration tunnel area to protect workers from the ionizing radiation hazards in the workplace. Measurement of gamma-ray exposure and radon gas concentrations were carried out in Remaja uranium exploration tunnel and around the workers camp in Kalan Area, West Kalimantan. Gamma exposure was measured using a gamma survey meter while radon (222Rn/220Rn) using RADUET passive detector. The concentrations of radon and thoron gas inside the tunnel generally are high, ranging from 188.84 to $495.86 \mathrm{~Bq} / \mathrm{m}^{3}\left(375.80 \mathrm{~Bq} / \mathrm{m}^{3}\right.$ average) and 58.07 to 340.73 $\mathrm{Bq} / \mathrm{m}^{3}\left(189.80 \mathrm{~Bq} / \mathrm{m}^{3}\right.$ average) respectively. These values are above the radon reference level $\left(300 \mathrm{~Bq} / \mathrm{m}^{3}\right)$ which is recommended by the International Commission on Radiation Protection (ICRP). The annual gamma effective dose reaches $147.88 \mathrm{mSv}$ inside the tunnel. This value is exceeding the $20 \mathrm{mSv}$ dose limit value for workers. It is necessary to control the exposure by fulfilled the principle of "as low as reasonably achievable" (ALARA) and external radiation protection to secure workers inside the tunnel from a health issue caused by gamma-ray, radon, and thoron exposures.
\end{abstract}

Keywords: risk assessment, gamma radiation, radon, miners, uranium tunnel 


\section{PENDAHULUAN}

Gas radon pada konsentrasi tinggi merupakan faktor risiko dari kanker paru dan penyebab kedua kanker paru di berbagai negara setelah rokok [1]. Perokok memiliki risiko 9 kali lebih tinggi terkena kanker paru dari bukan perokok sedangkan pekerja tambang uranium yang terpajan gas radon pada 40-240 Working Level Month (WLM) memiliki risiko 1,6-3,8 kali lebih tinggi untuk terkena kanker paru dari pekerja yang tidak terpajan gas radon. Risiko tersebut dapat meningkat menjadi 7 kali lebih tinggi jika pekerja tambang uranium tersebut adalah seorang perokok [2].

Untuk pajanan gas radon dengan konsentrasi rendah ( $<100$ WLM), analisis gabungan kelompok pekerja dengan karakteristik yang sama pada periode waktu tertentu dan memiliki riwayat pekerjaan yang sama (analisis kohort) dari Perancis, Ceko, dan Kanada (Beaverlodge) menyebutkan terdapat 62,9\% (408) kematian akibat kanker paru (rata-rata 36,42 WLM) dari jumlah seluruh kematian (649) akibat kanker paru kohort gabungan (rata-rata 95,49 WLM) [3]. Analisis ini menunjukkan bahwa pada konsentrasi rendah pun pajanan radon pada pekerja tambang dinilai masih berisiko.

Penilaian risiko pajanan radiasi gama, radon, dan turunan radon (toron) telah dilakukan pada bekas tambang uranium bawah tanah di Mesir. Hasil penelitian menunjukkan dosis tahunan dari pajanan radiasi gama berkisar antara $0,36-3,2 \mathrm{mSv}$. Hasil pajanan radiasi gama ini masih berada di bawah Nilai Batas Dosis (NBD) tahunan pekerja $20 \mathrm{mSv}$. Namun, untuk pajanan radon diperoleh nilai dosis tahunan berkisar antara 6-118 mSv dengan rata-rata $40 \mathrm{mSv}$. Sementara untuk pajanan toron didapatkan dosis tahunan yang berkisar antara 0,59-
$38,98 \mathrm{mSv}$ dengan rata-rata $10,18 \mathrm{mSv}$. Nilai pajanan radon dan toron yang dihasilkan pada penelitian tersebut berada di atas NBD tahunan pekerja [4].

Di Indonesia, kegiatan penelitian sumberdaya uranium telah dilakukan sejak tahun 1980 di daerah Kalan, Kalimantan Barat. Kegiatan yang dilakukan meliputi eksplorasi, pengeboran, peledakan, pengambilan bijih uranium, dan penyanggaan di terowongan eksplorasi uranium. Lingkup kegiatan tersebut hampir sama dengan kegiatan penambangan konvensional namun masih dalam skala pilot project. Saat ini, kegiatan yang masih dilakukan antara lain: studi geologi, pengambilan sampel batuan, pemantauan lingkungan, dan pemeliharaan penyangga terowongan. Meskipun demikian, risiko dari pajanan radiasi gama, radon, dan toron pada pekerja masih harus diantisipasi dan dikendalikan.

Dalam upaya melindungi pekerja dari bahaya fisika radiasi pengion di tempat kerja, penting untuk melakukan kajian risiko untuk mengetahui gambaran pajanan radiasi di dalam terowongan eksplorasi uranium Remaja dan kamp pekerja di Kalan, Kalimantan Barat. Dalam penelitian ini, dilakukan suatu kajian risiko dari pajanan radiasi gama, radon, dan toron pada pekerja di area terowongan eksplorasi uranium.

\section{TEORI}

Pajanan radiasi berpotensi merusak selsel hidup, menyebabkan kematian pada beberapa sel, dan menyebabkan modifikasi pada sel lainnya [5]. Secara umum efek-efek tersebut dihasilkan dari aksi radiasi langsung dan tidak langsung. Efek langsung dihasilkan oleh aksi awal radiasi itu sendiri, seperti putusnya rantai pada DNA yang disebabkan oleh peristiwa ionisasi dalam molekul. Efek 
tidak langsung dihasilkan melalui aksi kimia kemudian dari radikal bebas (atom, ion, atau molekul yang tidak stabil secara kimia) dan produk radiasi lainnya $[5,6]$.

Kategori pekerja yang terpajan radiasi pengion dalam jumlah terbanyak adalah mereka yang bekerja di industri penambangan dan pengolahan. Sumber utama pajanan radiasi di sebagian besar operasi penambangan adalah radon [7].

Radon adalah gas mulia yang muncul secara alami. Radon bersifat radioaktif dan dapat berasal dari peluruhan uranium-238 (U238) atau peluruhan torium-232 (Th-232). Uranium-238 adalah unsur radioaktif yang ditemukan di kerak bumi dengan waktu paruh 4,46 miliar tahun. Dua isotop yang sering dihubungkan dengan risiko kanker paru-paru adalah Radon-222 dan Radon-220 (toron). Radon-222 dihasilkan dari peluruhan radioaktif U-238, sedangkan Radon-220 (toron) dihasilkan dari peluruhan Th-232 [7]

International Commission on Radiation Protection (ICRP) tidak merekomendasikan penggunaan dosimetri pada organ pernafasan manusia untuk melakukan penilaian risiko dan pengendalian terhadap pajanan radon. Rekomendasi dari ICRP adalah perbandingan langsung terhadap satuan konsentrasi pajanan dan hasil konversi konsentrasi menjadi dosis efektif [7].

Proteksi dan pengendalian terhadap radon dilakukan dengan penerapan reference level dan optimisasi (Gambar 1). Pajanan radon dikendalikan dengan intervensi terhadap jalur pajanan (exposure pathways). Rekomendasi ICRP sebagai pembatas dosis untuk pajanan radon adalah $10 \mathrm{mSv}$ [8]. Selain itu, ICRP merekomendasikan nilai reference level sebesar $300 \mathrm{~Bq} / \mathrm{m}^{3}$ pada semua bangunan dan tempat kerja. Namun, otoritas nasional bertanggung jawab untuk menetapkan National Reference Level (NRL) atau Nilai Ambang Batas (NAB) masingmasing dengan mempertimbangkan keadaan ekonomi dan sosial yang berlaku dan kemudian menerapkan proses optimalisasi perlindungan di negara mereka [7].

Tindakan optimisasi dapat mencakup langkah-langkah perbaikan fisik (mitigasi) untuk mengurangi konsentrasi radon dan tindakan manajemen untuk membatasi akses. Pembatasan akses terutama berlaku untuk tempat kerja tanpa akses atau akses terbatas. Untuk tempat kerja semacam ini, pengukuran lebih lanjut diperlukan untuk mengetahui konsentrasi selama jam kerja sebagai bagian dari langkah kedua dalam pendekatan bertingkat.

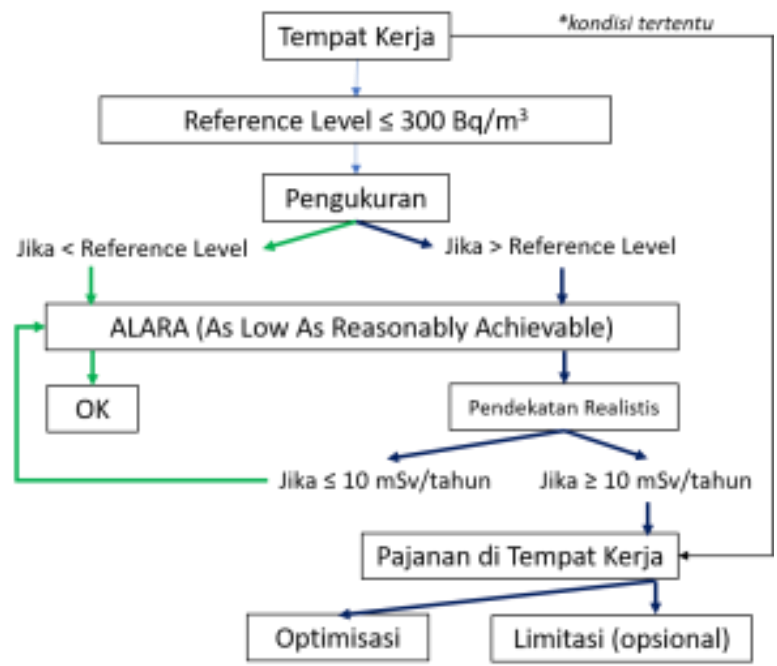

Gambar 1. Pendekatan bertingkat dalam penilaian risiko pajanan radon di tempat kerja $[7,9]$.

Terlepas dari ada atau tidaknya pajanan radon pada pekerja, pajanan radiasi yang diterima oleh pekerja harus tetap berada di bawah Nilai Batas Dosis (NBD) pada kondisi pajanan existing yaitu $20 \mathrm{mSv} / \mathrm{tahun}$. Konsep limitasi dosis harus diterapkan jika otoritas nasional menganggap pajanan radon pada suatu lokasi adalah kondisi pajanan terencana (planned exposure) [7]. 


\section{METODOLOGI}

\section{Pengambilan Data}

Penelitian dilakukan di terowongan eksplorasi uranium Remaja dan kamp pekerja di Kalan, Kalimantan Barat. Sampel penelitian sebanyak 14 titik di dalam terowongan eksplorasi uranium dan 15 titik di kamp pekerja. Lokasi pengukuran di dalam terowongan eksplorasi uranium dapat dilihat pada Gambar 2, sementara lokasi di kamp pekerja dapat dilihat pada Gambar 3.

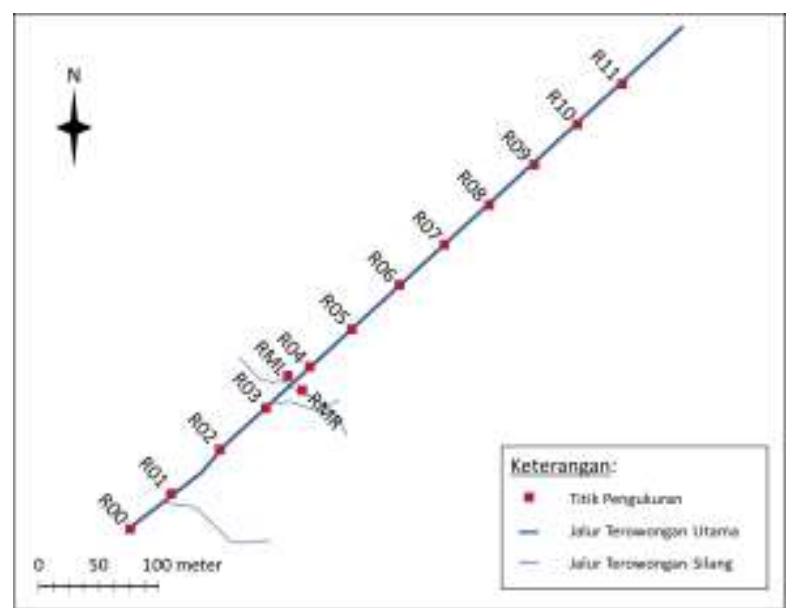

Gambar 2. Titik ukur di dalam terowongan eksplorasi uranium Remaja.

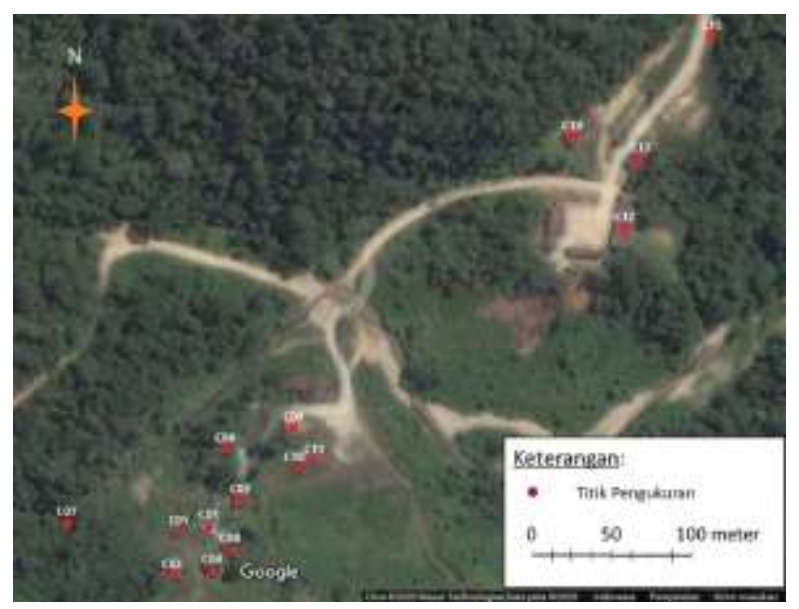

Gambar 3. Titik ukur di sekitar kamp pekerja.

Pengambilan data dilakukan dengan menggunakan alat ukur surveimeter radiasi gamma merk GammaScout yang telah dikalibarasi di Laboratorium Kalibrasi Pusat Teknologi Keselamatan dan Metrologi
Radiasi-BATAN dan RADUET (RadonThoron Discriminative Detector) merk Radosys yang merupakan detektor pasif untuk mendeteksi konsentrasi radon dan toron. Detektor RADUET terdiri dari dua ruang difusi, yaitu ruang difusi rendah dan tinggi. Kepingan CR-39 ditempatkan di setiap ruang untuk mendeteksi jejak partikel alfa [10].

Pengukuran laju dosis $(\mu \mathrm{Sv} / \mathrm{h})$ pajanan radiasi gama dilakukan pada jarak 1 meter dari tanah di setiap titik pemantauan. Pengukuran laju dosis ini dilakukan sesuai dengan protokol pengukuran internasional, yaitu 1 meter di atas tanah dan di permukaan tanah untuk kondisi tertentu $[4,10,11]$.

\section{Pengolahan Data}

Data laju dosis radiasi gama $(\mu \mathrm{Sv} / \mathrm{jam})$ hasil pengukuran menggunakan surveimeter diolah menjadi dosis radiasi gama tahunan (mSv/tahun) dengan menggunakan persamaan:

$D=\sum_{i} D_{i} \times O_{i} \times 10^{-3}$

Variabel $D$ adalah dosis radiasi gama tahunan (mSv/tahun), $D_{i}$ adalah laju dosis radiasi gama $(\mu \mathrm{Sv} / \mathrm{jam})$, dan $O_{i}$ adalah faktor durasi kerja (jam/tahun).

Dosis efektif radiasi tahunan (mSv/tahun) didapatkan dari hasil estimasi perhitungan berdasarkan persamaan [4]:

$E_{i}=(D C F \times F)_{R_{n} / T_{n}} \times \sum_{i} C_{i} \times O_{i} \times 10^{-6}$

Variabel $E_{i}$ adalah dosis efektif radiasi tahunan (mSv/tahun), $C_{i}$ adalah konsentrasi radon atau toron di titik ukur $i\left(\mathrm{~Bq} / \mathrm{m}^{3}\right), O_{i}$ adalah faktor durasi kerja (jam/tahun), $D C F$ adalah Dose Conversion Factor untuk radon $\left(9 \mathrm{nSv} \mathrm{jam}^{-1} \mathrm{~Bq}^{-1} \mathrm{~m}^{-3}\right.$ ) dan toron (40 $\mathrm{nSv}$ jam $\left.{ }^{1} \mathrm{~Bq}^{-1} \mathrm{~m}^{-3}\right), F$ adalah faktor ekuilibrium radon $(0,4)$ dan toron $(0,1)$ untuk di dalam ruangan [4]. 
Faktor durasi kerja (Oi) didapatkan dari asumsi durasi kerja pada lokasi titik ukur yang terdiri dari lokasi dengan jenis pajanan di tempat kerja dan pajanan di tempat tinggal. Untuk pajanan di tempat kerja digunakan durasi kerja 2.000 jam per tahun [9] sedangkan untuk pajanan di tempat tinggal digunakan durasi kerja 6.000 jam per tahun $[10,11]$.

\section{HASIL DAN PEMBAHASAN}

Konsentrasi radon dan toron di dalam terowongan Remaja menunjukkan hasil konsentrasi radon pada titik-titik tersebut berkisar antara 188,84 sampai 495,86 Bq/ $\mathrm{m}^{3}$ dan toron berkisar dari 58,07 hingga 340,73 $\mathrm{Bq} / \mathrm{m}^{3}$ (Tabel 1). Rata-rata konsentrasi radon di dalam terowongan adalah $375,80 \mathrm{~Bq} / \mathrm{m}^{3}$, sementara rata-rata konsentrasi toron adalah
$189,80 \mathrm{~Bq} / \mathrm{m}^{3}$. Data tersebut menunjukkan bahwa di dalam terowongan terdapat beberapa lokasi yang memiliki pajanan lebih tinggi dari batas yang direkomendasikan untuk pajanan radon di tempat kerja.

Hasil pengukuran laju dosis gama di dalam terowongan berkisar antara 0,42 hingga 73,94 $\mu \mathrm{Sv} / \mathrm{jam}$. Nilai pengukuran laju dosis gama tersebut kemudian dikonversi menjadi dosis efektif tahunan sehingga diperoleh nilai dosis efektif tahunan antara 0,85 hingga $147,88 \mathrm{mSv}$ dengan rata-rata 7,81 mSv (Tabel 1). Tingkat radiasi yang tinggi berkaitan dengan adanya mineralisasi di beberapa titik pengukuran. Hasil yang diperoleh secara umum masih sesuai dengan nilai pajanan radiasi yang direkomendasikan pada pekerja meskipun terdapat lokasi yang memiliki laju dosis radiasi gama di atas NBD.

Tabel 1. Konsentrasi radon, toron, laju dosis radiasi gama, dan dosis tahunan radon dan toron di dalam Terowongan Eksplorasi Uranium Remaja.

\begin{tabular}{cccccc}
\hline St. No & $\begin{array}{c}\text { CRn } \\
(\mathbf{B q} / \mathbf{m 3})\end{array}$ & $\begin{array}{c}\text { CTn } \\
(\mathbf{B q} / \mathbf{m} 3)\end{array}$ & $\begin{array}{c}\text { Dm } \\
(\mathbf{m S v} / \mathbf{t h})\end{array}$ & $\begin{array}{c}\text { ERn } \\
(\mathbf{m S v} / \mathbf{t h})\end{array}$ & $\begin{array}{c}\text { ETn } \\
(\mathbf{m S v} / \mathbf{t h})\end{array}$ \\
\hline R00 & 248,46 & 107,50 & 0,85 & 1,79 & 0,86 \\
$\mathbf{R 0 1}$ & 240,53 & 340,73 & 19,42 & 1,73 & 2,73 \\
$\mathbf{R 0 2}$ & 435,64 & 191,18 & 1,58 & 3,14 & 1,53 \\
$\mathbf{R 0 3}$ & 425,72 & 213,58 & 3,59 & 3,07 & 1,71 \\
R04 & 419,95 & 204,77 & 4,46 & 3,02 & 1,64 \\
R05 & 480,30 & 215,10 & 4,72 & 3,46 & 1,72 \\
R06 & 436,00 & 235,08 & 14,92 & 3,14 & 1,88 \\
R07 & 369,96 & 211,61 & 1,01 & 2,66 & 1,69 \\
R08 & 266,62 & 151,75 & 7,53 & 1,92 & 1,21 \\
R09 & 383,91 & 164,51 & 1,47 & 2,76 & 1,32 \\
R10 & 414,67 & 169,90 & 1,29 & 2,99 & 1,36 \\
R11 & 188,84 & 58,07 & 0,91 & 1,36 & 0,46 \\
RMR & 495,86 & 208,02 & 147,88 & 3,57 & 1,66 \\
RML & 454,74 & 185,47 & 8,99 & 3,27 & 1,48 \\
\hline min & 188,84 & 58,07 & 0,85 & 1,36 & 0,46 \\
\hline max & 495,86 & 340,73 & 147,88 & 3,57 & 2,73 \\
\hline Rata-rata & 375,80 & 189,80 & 15,62 & 2,71 & 1,52 \\
\hline CRn= Konsentrasi Radon & & & & \\
CTn= Konsentrasi Toron & & & & \\
Dm = Dosis efektif radiasi gama tahunan & & & \\
ERn= Dosis efektif tahunan dari Radon & & & \\
ETn= Dosis efektif tahunan dari Toron & & & & & \\
\hline
\end{tabular}


Jika pekerjaan di terowongan Remaja dilakukan dengan waktu pajanan 8 jam per hari, 5 hari per minggu, dan 50 minggu per tahun, maka total jam kerja efektif adalah 2.000 jam per tahun. Berdasarkan angka total jam kerja per tahun tersebut, maka diperoleh dosis efektif tahunan radon bagi para pekerja berkisar antara 1,36 hingga 3,57 mSv dengan rata-rata $2,71 \mathrm{mSv}$ sedangkan dosis efektif tahunan toron antara 0,46 sampai $2,73 \mathrm{mSv}$ dengan rata-rata $1,52 \mathrm{mSv}$. Hasil ini menunjukkan bahwa dosis efektif tahunan di dalam terowongan memiliki nilai lebih rendah dari batas yang disarankan.
Nilai konsentrasi radon di sekitar kamp pekerja berkisar antara 2,71 sampai 124,88 $\mathrm{Bq} / \mathrm{m}^{3}$ dan konsentrasi toron berkisar antara 33,94 hingga 303,82 Bq/ $\mathrm{m}^{3}$ (Tabel 2). Ratarata konsentrasi radon di sekitar kamp pekerja adalah $43,11 \mathrm{~Bq} / \mathrm{m}^{3}$ sementara rata-rata konsentrasi toron adalah $134,91 \mathrm{~Bq} / \mathrm{m}^{3}$. Berdasarkan data tersebut, maka pada area di sekitar kamp pekerja terdapat lokasi yang memiliki pajanan sedikit di atas batas yang direkomendasikan untuk pajanan radon di tempat kerja.

Tabel 2. Konsentrasi radon, toron, laju dosis radiasi gama, dosis tahunan radon dan toron di sekitar kamp pekerja.

\begin{tabular}{|c|c|c|c|c|c|}
\hline St. No & $\begin{array}{c}\text { CRn } \\
\left(\mathrm{Bq} / \mathrm{m}^{3}\right)\end{array}$ & $\begin{array}{c}\text { CTn } \\
\left(\mathrm{Bq} / \mathbf{m}^{3}\right)\end{array}$ & $\begin{array}{c}\text { Dm } \\
(\mathrm{mSv} / \mathrm{th})\end{array}$ & $\begin{array}{c}\text { ERn } \\
(\mathrm{mSv} / \mathrm{th})\end{array}$ & $\begin{array}{c}\text { ETn } \\
(\mathrm{mSv} / \mathrm{th})\end{array}$ \\
\hline C01 & 31,02 & 33,94 & 0,25 & 0,22 & 0,27 \\
\hline $\mathrm{CO2}$ & 11,78 & 216,10 & 1,06 & 0,25 & 5,19 \\
\hline $\mathrm{CO3}$ & 3,25 & 37,73 & 1,12 & 0,07 & 0,91 \\
\hline C04 & 50,80 & 34,33 & 0,72 & 1,10 & 0,82 \\
\hline $\mathrm{C05}$ & 9,48 & 127,68 & 0,95 & 0,20 & 3,06 \\
\hline C06 & 7,44 & 236,29 & 0,34 & 0,05 & 1,89 \\
\hline $\mathrm{C07}$ & 15,17 & 35,07 & 0,27 & 0,11 & 0,28 \\
\hline $\mathrm{C} 08$ & 55,26 & 218,41 & 0,83 & 1,19 & 5,24 \\
\hline C09 & 91,02 & 210,42 & 0,64 & 0,66 & 1,68 \\
\hline C10 & 120,01 & 141,46 & 0,81 & 0,86 & 1,13 \\
\hline C11 & 103,49 & 178,80 & 2,87 & 0,75 & 1,43 \\
\hline $\mathrm{C} 12$ & 10,97 & 48,03 & 0,25 & 0,08 & 0,38 \\
\hline C13 & 9,34 & 134,92 & 0,37 & 0,07 & 1,08 \\
\hline C14 & 124,88 & 303,82 & 0,51 & 0,90 & 2,43 \\
\hline C15 & 2,71 & 66,70 & 1,34 & 0,06 & 1,60 \\
\hline $\min$ & 2,71 & 33,94 & 0,25 & 0,05 & 0,27 \\
\hline $\max$ & 124,88 & 303,82 & 2,87 & 1,19 & 5,24 \\
\hline Rata-rata & 43,11 & 134,91 & 0,82 & 0,44 & 1,83 \\
\hline \multicolumn{6}{|c|}{$\begin{array}{l}\text { CRn = Konsentrasi Radon } \\
\text { CTn = Konsentrasi Toron } \\
\text { Dm = Dosis efektif radiasi gama tahunan } \\
\text { ERn = Dosis efektif tahunan dari Radon } \\
\text { ETn = Dosis efektif tahunan dari Toron }\end{array}$} \\
\hline
\end{tabular}

Hasil pengukuran laju dosis gama di nilai dosis efektif tahunan di area kamp kamp pekerja menunjukkan nilai antara 0,125 hingga $1,433 \mu \mathrm{S} v /$ jam. Jika dikonversikan pekerjaan antara 0,25 hingga $2,87 \mathrm{mSv}$ dan menjadi nilai dosis efektif tahunan, maka rata-rata $0,82 \mathrm{mSv}$ (Tabel 2). Nilai tersebut secara umum masih sesuai dengan nilai 
pajanan radiasi yang direkomendasikan pada pekerja. Tidak ada lokasi yang memiliki dosis radiasi gamma di atas NBD di area kamp pekerja.

Hasil dosis efektif tahunan radon berkisar antara 0,05 hingga $1,19 \mathrm{mSv}$ dengan rata-rata $0,44 \mathrm{mSv}$. Sementara dosis efektif tahunan toron antara 0,27 hingga 5,24 $\mathrm{mSv}$ dengan rata-rata $1,83 \mathrm{mSv}$. Hasil ini menunjukkan dosis efektif tahunan di area kamp pekerja masih lebih rendah dari batas yang disarankan.

Dosis efektif tahunan dari pajanan radon dan toron di dalam terowongan tidak melebihi $10 \mathrm{mSv}$, tetapi terdapat lokasi yang memiliki nilai pajanan radiasi gama melebihi NBD, yaitu mencapai $147,88 \mathrm{mSv}$. Dalam hal ini, perlu dilakukan intervensi untuk melindungi pekerja berupa proteksi radiasi eksternal, diantaranya: membatasi waktu pajanan, memperbesar jarak dari sumber, dan menggunakan penahan radiasi [6,7]. Untuk menghindari pajanan konsentrasi radon dan toron yang tinggi dapat dirancang sistem ventilasi untuk mengalirkan udara luar ke dalam terowongan sebelum pekerja memulai kegiatan.

Hasil pengukuran di kamp pekerja menunjukkan nilai pajanan radiasi gama dan gas radon relatif rendah. Data pengukuran gas radon dan toron menunjukkan hanya terdapat satu lokasi yang memiliki konsentrasi lebih tinggi dari reference level. Konsentrasi tinggi tersebut dapat dipengaruhi beberapa faktor seperti temperatur, kelembaban, sirkulasi udara, dan kecepatan angin pada lokasi pengukuran [12]. Untuk menghindari pajanan konsentrasi yang tinggi dapat dilakukan perbaikan sirkulasi udara di lokasi terkait.

\section{KESIMPULAN}

Pekerja yang berada di dalam lokasi terowongan eksplorasi uranium berpotensi terpajan radiasi eksterna dan interna. Pajanan radiasi eksterna berasal dari radiasi gama, sementara pajanan radiasi interna berasal dari gas radon dan toron. Rata-rata konsentrasi radon di dalam terowongan Remaja rata-rata $375,80 \mathrm{~Bq} / \mathrm{m}^{3}$ sementara konsentrasi toron berkisar antara 58,07 hingga $340,73 \mathrm{~Bq} / \mathrm{m}^{3}$ dengan rata-rata $189,80 \mathrm{~Bq} / \mathrm{m}^{3}$. Secara umum konsentrasi gas radon dan toron di beberapa lokasi di dalam terowongan cukup tinggi, di atas reference level sebesar $300 \mathrm{~Bq} / \mathrm{m}^{3}$ yang direkomendasikan oleh ICRP. Selain itu, terdapat lokasi di dalam terowongan yang memiliki nilai dosis tahunan dari pajanan radiasi gama mencapai $147,88 \mathrm{mSv}$. Nilai dosis efektif tahunan dari sinar gama tersebut berada di atas nilai batas dosis $20 \mathrm{mSv}$ untuk pekerja. Pada area kamp pekerja, nilai pajanan radiasi gama dan gas radon relatif rendah namun terdapat 1 lokasi yang memiliki nilai pajanan diatas reference level. Diperlukan pengendalian dengan memenuhi prinsip ALARA seperti pemasangan sistem ventilasi untuk mengalirkan udara luar ke dalam terowongan sebelum pekerja memulai kegiatan agar pajanan radon dan toron tidak mengakibatkan kanker paru. Selain itu diperlukan proteksi radiasi eksterna bagi pekerja di dalam terowongan agar tidak menyebabkan masalah kesehatan lain dari radiasi gama.

\section{UCAPAN TERIMA KASIH}

Penulis mengucapkan terima kasih kepada Profesor Shinji Tokonami, PhD., di Universitas Hirosaki, Jepang yang telah memfasilitasi penggunaan RADUET dalam penelitian ini. Penulis juga berterima kasih kepada Kepala Pusat Teknologi Bahan Galian Nuklir-Badan Tenaga Nuklir Nasional (PTBGN-BATAN), Arya Pramana Sembiring, Suci Indryati, dan Widyarti Norma Pratiwi untuk bantuan pengambilan 
data, serta Departemen K3 FKM UI. Penelitian ini didanai oleh Beasiswa PUSDIKLAT BATAN, DIPA PTBGNBATAN Tahun 2019, dan Universitas Hirosaki, Jepang.

\section{DAFTAR PUSTAKA}

[1] M. Torres-Durán, J. M. Barros-Dios, A Fernández-Villar, dan A. Ruano-Ravina, "Residential Radon and Lung Cancer in Never Smokers. A Systematic Review," Cancer Lett., vol. 345, no. 1, pp. 21-26, 2014, doi: 10.1016/j.canlet.2013.12.010.

[2] K. Leuraud, M. Schnelzer, L. Tomasek, N. Hunter, M. Timarche, B. Grosche, M. Kreuzer, dan D. Laurier, "Radon, Smoking and Lung Cancer Risk: Results of a Joint Analysis of Three European Case-Control Studies Among Uranium Miners," Radiat. Res., vol. 176, no. 3, pp. 375387, 2011, doi: 10.1667/rr2377.1.

[3] R. S. D. Lane, L. Tomášek, L. B. Zablotska, E. Rage, F. Momoli, dan J. Little, "Low Radon Exposures and Lung Cancer Risk: Joint Analysis of the Czech, French, and Beaverlodge Cohorts of Uranium Miners," Int. Arch. Occup. Environ. Health, vol. 92, pp. 747-762, 2019, doi: 10.1007/s00420-019-01411-w.

[4] M. Y. M. Hanfi, "Radiological Assessment of Gamma and Radon Dose Rates at Former Uranium Mining Tunnels in Egypt," Environ. Earth Sci., vol. 78, no. 4, pp. 1-7, 2019, doi: 10.1007/s12665-019-8089-3.

[5] B. J. Vincelli, N. W. Henry, J. J. Miller, dan J. R. Weldy, Radiation Safety Officer Survival
Handbook. American Industrial Hygiene Association (AIHA), 2009.

[6] H. Mu, J. Sun, L. Li, J. Yin, N. Hu, W. Zhao, D. Ding, dan L. Yi, "Ionizing Radiation Exposure: Hazards, Prevention, and Biomarker Screening," Environ. Sci. Pollut. Res., vol. 25, no. 16, pp. 15294-15306, 2018, doi: 10.1007/s11356-0182097-9.

[7] ICRP, Radiological protection against radon exposure, ICRP 126., vol. 43, no. 3. SAGE Publications, 2014.

[8] ICRP, Protection Against Radon-222 at Home and at Work, ICRP 65., vol. 23, no. 2. 1993.

[9] J. W. Marsh, D. Laurier, dan M. Tirmarche, "Radon Dosimetry for Workers: ICRP's Approach," J. Radiat. Prot. Dosim., vol. 177, no. 4, pp. 466-474, 2017, doi: 10.1093/rpd/ncx065.

[10] S. Tokonami, H. Takahashi, Y. Kobayashi, W. Zhuo, dan E. Hulber, "Up-to-date Radon-Thoron Discriminative Detector for a Large Scale Survey," Rev. Sci. Instrum., vol. 76, no. 11, pp. 1-5, 2005, doi: 10.1063/1.2132270.

[11] P. Stegnar, I. Shishkov, M. Burkitbayev, B. Tolongutov, M. Yunusov, R. Radyuk, dan B. Salbu, "Assessment of the Radiological Impact of Gamma and Radon Dose Ratesat Former U Mining Sites in Central Asia," J. Environ. Radioact., vol. 123, pp. 3-13, 2013, doi: 10.1016/j.jenvrad.2012.12.005.

[12] E. Lespukh, P. Stegnar, M. Yunusov, H. Tilloboev, G. Zyazev, P. Kayukov, A. Hosseini, G. Strømman, dan B. Salbu, "Assessment of the Radiological Impact of Gamma and Radon Dose Rates at Former U Mining Sites in Tajikistan," $J$. Environ. Radioact., vol. 126, pp. 147-155, 2013, doi: 10.1016/j.jenvrad.2013.07.019. 